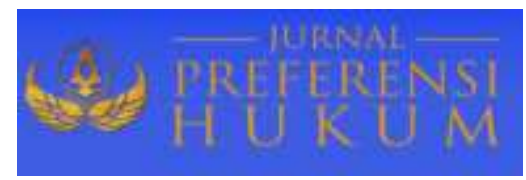

Jurnal Preferensi Hukum | ISSN: 2746-5039

Vol. 2, No. 2 - Juli 2021, Hal. 359-364| Available online at

https://www.ejournal.warmadewa.ac.id/index.php/juprehum

DOI: https://doi.org/10.22225/jph.2.2.3338.359-364

\title{
PERLINDUNGAN HUKUM TERHADAP ANAK PENYANDANG DISABILITAS SEBAGAI KORBAN KEKERASAN SEKSUAL
}

\author{
Nadila Purnama Sari, Anak Agung Sagung Laksmi Dewi, Luh Putu Suryani \\ Fakultas Hukum, Universitas Warmadewa, Denpasar-Bali, Indonesia \\ nadilapurnamas@gmail.com, laksmiidewi29@gmail.com, putusuryani099@gmail.com
}

\begin{abstract}
Abstrak
Anak penyandang disabilitas sering kali menjadi target utama untuk dijadikan sebagai korban dari para pelaku kejahatan, diskriminasi serta kekerasan seksual hal berikut dapat dilihat dari bertambahnya perkara kriminal kepada perempuan dan anak penyandang disabilitas yang dari tahun ke tahun cenderung meningkat. Tujuan dari penelitian ini guna mengetahui perlindungan hukum terhadap anak penyandang disabilitas sebagai korban kekerasan seksual dan sanksi pidana terhadap pelaku kekerasan seksual terhadap anak penyandang disabilitas. Metode yang digunakan merupakan metode normatif beserta pendekatan perundang-undangan dan konseptual. Hasil pengkajian mengatakan bahwa perlindungan hukum terhadap anak sebagai korban kekerasan seksual terdapat dalam pasal 1 ayat (2) UU No. 35 tahun 2014 tentang perlindungan anak yaitu agar anak tersebut mendapat pengamanan dan haknya selaku anak. Sanksi pidana bagi pelaku kekerasan seksual terhadap penyandang Disabilitas ada di dalam hukum positif di Indonesia. Perbuatan pidana pemerkosaan terdapat didalam Pasal 285 sampai 288 KUHP. Kekerasan kepada anak penyandang disabilitas belum ada undang-undang yang mengatur secara khusus tetapi dalam VU No. 35 Tahun 2014 Tentang Perlindungan Anak terdapat pada Pasal 290 ayat (1) diancam beserta kurang lebih 7 tahun kurungan penjara.
\end{abstract}

Kata Kunci: Kekerasan Seksual, Perlindungan Anak, Penyandang Disabilitas.

\begin{abstract}
Children with disabilities are often the main targets to be victims of criminals, discrimination and sexual violence. The following can be seen from the increase in criminal cases against women and children with disabilities which from year to year tends to increase. The purpose of this study is to determine the legal protection of children with disabilities as victims of sexual violence and criminal sanctions against perpetrators of sexual violence against children with disabilities. The method used is a normative method along with statutory and conceptual approaches. The results of the study show that legal protection for children as victims of sexual violence is contained in article 1 paragraph (2) of Law no. 35 of 2014 concerning child protection, namely so that the child gets protection and his rights as a child. Criminal sanctions for perpetrators of sexual violence against persons with disabilities exist in positive law in Indonesia. The criminal act of rape is contained in Articles 285 to 288 of the Criminal Code. Violence against children with disabilities there is no law that specifically regulates it but in VU No. 35 of 2014 concerning Child Protection in Article 290 paragraph (1) is threatened with approximately 7 years of imprisonment.
\end{abstract}

Keywords: Sexual Violence, Child Protection, Persons with Disabilities.

\section{PENDAHULUAN}

Indonesia yaitu negara yang berlandaskan atas hukum, hingga tindakan orang atau rakyat yang merupakan kegiatan hidupnya harus berdasarkan aturan dan norma yang berlangsung di publik. Hukum tidak lepas dari aktivitas orang sebab hukum yaitu ketentuan buat mengendalikan kelakuan orang di aktivitasnya lantaran jikalau tidak adanya peraturan tidak bisa dibayangkan akan bagaimana kelak negeri ini, Kriminal saat ini terus rneningkat melalui gaya yang berlainan terlebih beserta perlengkapan yang bertambah canggih dan modern hingga kriminal akan bertambah rnerisaukan rakyat.

Kekerasan seksual sekarang ini menjadi kasus yang tidak ada berhentinya diperdebatkan, khususnya atas kejadian pencabulan terhadap anak dibawah umur, pelakunya tidak peduli kedudukan, jabatan, status, pendidikan, dan umur. Seluruh ini diperbuat kalau pelaku merasa terlampiaskan melalui hawa nafsunya, semasih perseorangan tengah memiliki daya pikat seksual dari anak-anak hingga kakekkakek besar kemungkinan bakal bisa melangsungkan tindak pencabulan bahkan memperkosa.

Anak Disabilitas adalah seorang anak yang mempunyai keistimewaan yang tidak pernah dimiliki oleh anak-anak pada umumnya. Anak yang juga menyandang sebagai kaum disabilitas 
memiliki kedudukan yang rawan dan kurang menguntungkan, dalam hal ini yang dmaksud kurang menguntungkan ialah bahwa anak penyandang disabilitas mengalami resiko yang sangat besar untuk mengalami ganguan dan tindakan pidana (Maidin, 2012)

Perlindungan anak yaitu upaya untuk mengadakan keadaan dimana semua anak bisa melangsungkan kewajiban dan haknya. Adapun pelaksanaan adanya keseimbangan pada suatu masyarakat, dengan begitu perlindungan hukum patut diusahakan pada berbagai aspek aktivitas bemegara dan bermasyarakat. Pada UU No. 8 tahun 2016 menentukan penyandang disabilitas yaitu tiap individu yang mempunyai keterbatasan fisik, intelektual, mental dan atau sensorik pada tempo yang cukup lama yang saat berinteraksi beserta lingkungan bisa dirasakan kesulitan dan hambatan untuk ikut serta dan efektif dengan penduduk lainnya berlandaskan kesetaraan hak. Dalam kehidupan nyata anak penyandang disabilitas sering kali menjadi target utama untuk dijadikan sebagai korban dari para pelaku kejahatan, diskriminasi serta kekerasan seksual hal berikut dapat dilihat dari melonjaknya perkara kekerasan kepada perempuan dan anak penyandang disabilitas yang dari tahun ke tahun cenderung meni ngkat.

Kekerasan seksual terhadap anak merupakan salah satu wujud dari kejahatan yang baru, yang menyangkut anak sebagai generasi penerus bangsa, sehingga kejahatan yang cukup mendapat perhatian di kalangan masyarakat. Sering kita ketahui, di koran atau majalah diberitakan terjadi kekerasan seksual. Kekerasan seksual ini tidak hanya terjadi di kota-kota besar yang relatif lebih maju kebudayaan dan kesadaran atau pengetahuan hukumnya, tapi juga terjadi di pedesaan yang relatif masih memegang nilai tradisi dan adat istiadat (Abu Huraerah, 2012).

Korban ialah orang yang mengalami suaru perlakuan buruk, diskriminasi serta kekerasan seksual dari orang lain. Korban juga yaitu seseorang yang mengalami kerugian tergolong Iuka fisik dan mental, kesengsaraan emosional, kerugian ekonomi maupun pengingkaran terhadap hak asasinya.

Penegakan aturan pidana yaitu suatu penanganan kepada kriminal yang perlu diberantas atau dijaga biar berada dalam keadaan terbatas. Implementasi penegakan aturan yang baik yang berlandaskan pedoman proporsional mesti berupaya membuat nilai keseimbangan secara keseluruhan, yang meliputi nilai keseimbangan oleh pihak korban, pihak pelaku kriminal, maupun kepada pihak rakyat sebagai keseluruhan.

Pengaturan sanksi pidana bagi pelaku tindak pidana pencabulan terhadap anak penyandang disabilitas belum ada undang-undang yang mengatur secara khusus namu didalam undangundang perllindungan anak nomor 35 tahun 2014, dan peraturan pemerintah penggangti undang-undang nomor 1 tahun 2016 perubahan kedua atas undang-undang nomor 23 tahun 2002 tentang perlindungan anak. Mengaturterkait sanksi pidana bagi pelaku tindak pidana kejahatan kekerasan seksual terhadap anak dan sanksi pidana bagi pelaku tindak pidana pencabulan terhadap anak (Ahmad Mukmin 2020).

Dalam penyusunan penelitian ini, peneliti mengambil referensi pada penelitian sebelumnya yaitu penelitian yang dilakukan oleh Ahmad Mukmin "Perlindungan Hukum Bagi Anak Penyandang Disabilitas Sebagai Korban Pencabulan Oleh Orang Tua". Yulianti Ningsih Cahyani, Alfa Galih Verdiantoro, Febriyanti Uma. "Perlindungan Hukum Bagi Korban Tindak Kekerasan Seksual Kaum Tunarungu dalam Perspektif Hukum Pidana". Perlindungan Hukum Terhadap Anak Korban Kekerasan Seksual (Studi Di Desa Sabrang Kecamatan Ambulu Kabupaten Jember).

Tujuan dilakukannya penelitian ini untuk mengetahui perlindungan hukum terhadap anak penyandang disabilitas sebagai korban kekerasan seksual dan mengetahui sanksi pidana terhadap pelaku kekerasan seksual terhadap anak penyandang disabilitas.

\section{METODEPENELITIAN}

Tipe penelitian yang dipakai yakni tipe penelitian hukum normatif yang penelitian hukurnnya meninjau hukum tertulis dari beragam aspek, namun tidak meninjau segi terapan atau implementasinya. Melainkan pendekatan masalah yang dipakai yakni pendekatan perundang-undangan yakni dijalankan melalui menganalisis peraturan perundang-undangan yang bersangkutan pada permasalahan, dan pendekatan konseprual yang berturnpu dari doktrin-doktrin beserta perundang-undang yang bertumbuh kembang di dalam ilmu hukum berfungsi memperjelas tanggapan beserta membagikan konsep hukum, pengertian-pengertian hukum, begitupun atas hukum yang relevan dengan persoalan sebagai cara memecahkan persoalan terhadap hukuman bagi pelaku kekerasan seksual kepada anak penyandang disabilitas. Adapun sumber bahan yang dipakai yakni sumber bahan hukum primer yakni KUHP, UU No. 35 Tahun 2014 Tentang Perlindungan Anak, UU No. 39 Tahun 1999 Tentang Hak Asasi Manusia, 
UU No. 8 Tahun 2016 Tentang Penyandang Disabilitas, dan sumber bahan hukum sekunder yakni bahan hukum yang didapat dari literatur seperti buku-buku referensi, jumal hukum, dan yang lain terpaut pada persoalan.

\section{HASIL PENELITIAN DAN PEMBAHASAN}

\section{Perlindungan Hukum Terhadap Anak Penyandang Disabilitas Sebagai Korban Kekerasan} Seksual

Kata disabilitas bermula dari Bahasa lnggris yakni different ability yang memiliki arti setiap orang mempunyai kemampuan yang berlainan. Adapun sejumlah penyebutan untuk penyandang disabilitas, Kementerian Pendidikan menamakan penyandang disabilitas dijuluki sebagai berkebutuhan khusus, Kementrian Kesehatan menamai penyandang disabilitas dijuluki sebagai penderita cacat, dan Kementrian Sosial menarnai penyandang disabilitas dijuluki sebagai penyandang cacat.

Penyandang disabilitas yakni semua individu yang mempunyai keterbatasan fisik, mental, intelektual, dan atau sensorik pada tempo yang cukup lama yang saat berinteraksi bersama lingkungan bisa dirasakan kesulitas dan hambatan untuk ikut serta secara penuh dan efektif dengan penduduk lainnya berlandaskan kesetaraan hak. Penjelasan tersebut dinyatakan pada UU No. 8 Tahun 2016. Adapun berdasarkan UU No. 39 Tahun 1999, penyandang cacat atau disabilitas yaitu golongan rakyat rentan yang mempunyai hak untuk mendapatkan perbuatan dan perlindungan yang lebih khusus.

Anak yaitu seorang perempuan ataupun lelaki yang belum dewasa atau belum mengalami masa pubertas. Anak-anak yakni manusia muda pada umur muda pada jiwa dan perjalanan hidupnya sebab gampang terhasut akan kondisi sekitarnya. Oleh sebab itu anak-anak harus diperhatikan dengan benarbenar. Namun, selaku makhluk sosial yang teramat rentan dan lemah, ironisnya anak-anak malah terkadang ditaruh pada posisi yang amat di rugikan, tidak mempunyai kebebasan buat berpendapat, terlebih kerap sebagai korban perbuatan kekerasan dan pelanggaran kepada hak-haknya. Pada Pasal 1 ayat (1) UU No.35 Tahun 2014 Tentang Perlindungan Anak yaitu tercantum seorang yang belum berumur 18 tahun, tercantum anak yang tengah di dalam kandungan.

Penjelasan kekerasan seksual pada KBBI yakni berhubungan pada seks (jenis kelamin), berhubungan antara lelaki dan wanita. Kekerasan yakni kelakuan yang memicu bahaya ataupun kerugian fisik, finansial, maupun psikologis, baik yang dirasakan pribadi ataupun kelompok. Kekerasan seksual yaitu persetubuhan yang tidak diinginkan oleh siapapun. Maka, kekerasan seksual dapat diartikan sebagai segala bentuk intirnidasi serta pemaksaan seksual.

Pokok pada kekerasan seksual terdapat dalam ancaman (verbal) dan pemaksaan (tindakan). Unsur-unsur yang terdapat pada pengertian dan yang terdapat di dalam pasal 285 dan 289 KUHP antara lain unsur ancaman, memaksa, dan memperkosa. Dari unsur-unsur yang terdapat pada penjelasan kekerasan seksual itu bisa dikelompokan kedalam dua kelompok besar sifat dari kekerasan tersebut, yaitu

1. Kekerasan pada Wujud Verbal (Mengancam)

Ancaman merupakan perbuatan rnenakut-nakuti. Dengan tujuan agar orang lain berbuat sesuai dengan ambisi pihak yang menakut-nakuti.

2. Kekerasan pada Benruk Perbuatan Konkret (Memaksa Dan Memperkosa)

Memaksa adalah perintah, memperlakukan, menyuruh, dan merninta dengan paksa dari orang lain buat melakukan suatu yang dikehendakinya. Biarpun orang tersebut tidak ingin melakukannya, akan tetapi orang yang menyodorkan suruhan mewajibkan orang itu untuk melakukannya.

Sedangkan memperkosa yaitu perbuatan kriminal bersifat seksual yang berlangsung ketika seseorang atau lebih mengharuskan orang lain buat melaksanakan hubungan seksual dalam benruk penetrasi vagina atau anus dengan penis, bagian tubuh lainnya semacam tangan, atau melalui bendabenda tertentu dengan memaksa baik serta kekerasan ataupun ancaman kekerasan. Jadi, istilah memperkosa ini mempunyai muatan pengertian yang serupa dengan memaksa, yaitu setara bentuk dari perbuatan Cuma perbedaannya perbuatan memaksa tidak mesti berupa persetubuhan, sedangkan memperkosa jelas telah berwujud persetubuhan terlepas dari persetubuhan itu tel ah dilaksanakan antar orang dewasa ataupun antara orang dewasa dengan anak.

Kekerasan seksual bisa berlangsung dimana saja baik di tempat umum seperti sekolah, bis, kantor, pasar, atau di rumah. Walaupun wanita secara umum sering menjadi korban kekerasan seksual, namun korban kekerasan seksual bisa siapa saja. Korban dari kekerasan seksual dapat jadi lelaki maupun wanita. Kasus kekerasan seksual kepada anak yang pada saat ini semakin meningkat. Dimana 
anak menjadi subjek pemuas seksual yang diperbuat oleh orang-orang sekitar mereka terutama orang dewasa buat memperoleh kenikmatan maupun kepuasan seksual.

Bentuk perlindungan hukum dibagi jadi 2 yakni preventif dan represif sebagai berikut:

1. Perlindungan Hukum Preventif

Perlindungan hukum yang diberikan oleh pemerintah bertujuan buat mencegah sebelum berlangsungnya pelanggaran. Hal tersebut termuat pada peraturan perundang-undangan dengan arti buat menghindari tindakan kriminal dan menyampaikan rambu-rarnbu ataupun batasan pada saat melaksanakan suatu kewajiban. Tujuannya adalah buat mencegah adanya sengketa. Subyek hukum diberikan peluang buat mengungkapkan pendapatnya sebelum putusan pemerintah memperoleh cara yang definitive. Perlindungan hukum preventif artinya cukup besar pada tindak pemerintah yang berdasarkan atas keleluasaan berbuat lantaran melalui perlindungan hukum ini pemerintah termotivasi buar bersifat hati-hati saat mengambil kepurusan yang berdasarkan pada diskresi.

2. Perlindungan Hukum Represif

Perlindungan hukum represif yaitu perlindungan akhir berbentuk hukuman berupa penjara, denda, dan hukuman tambahan yang diserahkan seandainya telah berlangsung sengketa ataupun udah terjadinya pelanggaran. Prinsip perlindungan hukum kepada kegiatan pemerintah berasal dan berpijak berawal konsep mengenai kesaksian dan perlindungan terhadap HAM sebab menurut sejarah, lahirnya konsep-konsep mengenai perlindungan dan pengakuan terhadap HAM diarahkan pada batasan dan penempatan kewajiban masyarakat dan pemerintah. Pokok yang melandasi perlindungan hukum kepada tindak pemerintah yaitu pokok negara hukum. Disamakan beserta dengan perlindungan dan pengakuan kepada HAM, perlindungan dan pengakuan kepada HAM memperoleh posisi pertama dan bisa disamakan dengan tujuan dari negara hukum. Penanganan perlindungan hukum dari Pengadilan Umum dan Pengadilan Administrasi di Indonesia tercantum dalam jenis perlindungan hukum.

Sama halnya penyandang disabilitas yang sangat memerlukan sebuah perlindungan hukum bagi dirinya hal tersebut dikarenakan selain kekurangan yang mereka miliki adanya faktor lain yang berupa tindakan yang tidak mengenakan sering kali didapatkan oleh penyandang disabilitas seperti hinaan yang sering kali diucapkan oleh seseorang mengenai kekurangan penyandang disabilitas tersebut, kemudian kekerasan fisik yang sering kali juga diperoleh oleh penyandang disabilitas tersebut. Dengan adanya UU No.8 Tahun 2016 maka seorang penyandang disabilitas dapat merasa aman baik secara pikiran maupun fisik.

Perlakuan yang tidak baik serta keadilan yang dirasa kurang sering dirasakan oleh setiap penyandang disabilitas di dalam lingkungan hidupnya hal ini sering menjadi pemicu para penyandang disabilitas mengurung dirinya bahkan tidak ingin ikut serta dalam kegiatan yang ada.

Perlindungan hukum kepada anak yaitu segenap usaha yang diperbuat agar semua anak mendapatkan kewajiban dan haknya demi pertumbuhan dan perkembangannya secara wajar baik sosial, fisik, dan mental. Perlindungan anak yaitu terwujudnya adanya keseimbangan pada suatu masyarakat, sedemikian itu perlindungan anak diusahakan pada beragam bidang, aktivitas dan bermasyarakat. Upaya perlindungan anak tidak boleh menyebabkan matinya kreatifitas, inisiatif, dan hal-hal lain yang mengakibatkan bergantung kepada orang lain dan berbuat tidak terarah, hingga anak rak mempunyai kecakapan dan keinginan memakai haknya dan melakukan kewajibannya.

Perlindungan hukum terhadap anak selaku korban kekerasan seksual terdapat pada Pas al 1 ayat (2) UU No. 35 Tahun 2014 yaitu agar anak tersebut mendapat perlindungan dan haknya selaku anak juga dilindungi hak bagi hidupnya, berrumbuh kembang dan ikut serta secara optimal setimpal pada harkat dan martabat kemanusiaan, beserta perlindungan hukum diberikan agar memperoleh perlindungan atas kekerasan dan diskriminasi yang akan menimpa anak.

\section{Sanksi Pidana Bagi Pelaku Kekerasan Seksual Terhadap Anak Penyandang Disabilitas}

Sanksi yaitu sebutkan yang sering dipakai dalam berbagai macam aruran hukum di kalangan masyarakat, salah sarunya yakni pada KUHP. Hingga pemakaian kalimat sanksi dalam KUHP, seringkali disebut menjadi sanksi pidana atau justru cuma disebut pidana saja (punishment).

Hukuman yaitu sebutan umum dan konvensional, bisa memiliki yang berarti luas dan berubahubah sebab istilah itu bisa berkonotasi melalui bersama bidang yang lumayan luas, semacam di bidang moral, agama, pendidikan, dan lain-lain. Oleh sebab itu pidana yaitu sebutan yang lebih khusus, maka 
butuh adanya batasan pengertian atau definisi sentral yang bisa menunjukan ciri-ciri maupun sifatnya yang khas.

Sanksi pidana yaitu hukuman sebab akibat, dimana sebab yang yang dimaksud yaitu kasusnya dan akibat yakni hukumannya. Seseorang yang kena akibat bakal menerima hukuman baik masuk penjara atau mendapat hukuman lainnya oleh pihak yang berwajib. Sanksi pidana yakni jenis sanksi yang bersifat nestapa yang diancarnkan ataupun dikenai kepada pelaku tindak pidana yang bisa merisaukan ataupun mencelakakan kepentingan hukum. Sanksi pidana atas dasamya yaitu suatu penanggung buat merehabilitasi kelakuan dari pelaku kejahatan, akan tetapi tidak sedikit sanksi pidana dibentuk menjadi suatu ancaman pada keleluasaan orang itu sendiri.

Hukum pidana di Indonesia mempunyai dua sanksi pidana yang diatur pada Pasal 10 KUHP sebagai berikut:

1. Hukum Pidana Pokok

a. Hukum Pidana mati

b. Hukum Pidana penjara

c. Hukum Pidana kurungan

d. Hukum Pidana denda

2. Hukum Pidana Tambahan

a. Pencabulan hak-hak tertentu

b. Perampasan barang-barang tertentu c. Pengumuman putusan hakim

Kekerasan seksual kepada anak dari tahun ke tahun selalu mengalami peningkatan kasus yang signifikan, yang dapat membahayakan jiwa anak, tumbuh kembang anak dan dapat mengganggu kenyamanan serta ketertiban di Masyarakat. Banyaknya kasus kekerasan seksual terhadap anak penyandang disabilitas dikarenakan anak belum mengetahui bahaya dari berhubungan badan dan itu menjadi faktor orang yang lebih dewasa untuk memanfaatkan hal tersebut.

Sanksi pidana bagi pelaku kekerasan seksual terhadap penyandang Disabilitas ada di dalam hukum positif di Indonesia. Tindak pidana pemerkosaan terdapat didalam Pasal 285 sampai 288 KUHP. Disabilitas yang merujuk pada Pasal 285 dan 286 KUHP adalah dalam kondisi tidak berdaya sebab mempunyai keterbelakangan mental hingga tidak bisa berpikir layaknya orang biasa. Sanksi pidana bagi pelaku kekerasan seksual terhadap penyandang disabilitas belum ada Undang-Undang yang mengaturnya secara khusus, namun dalam UU No. 35 Tahun 2014 Tentang Perlindungan Anak terdapat dalam Pasal 290 Ayat (1) yang diancam kurang lebih 7 tahun kurungan penjara.

\section{SIMPULAN DAN SARAN}

\section{Simpulan}

dari paparan penjelasan penelitian ini maka disimpulkan bahwa perlindungan hukum kepada anak penyandang disabilitas terdapat pada Pasal I ayat 2 UU No. 35 Tahun 2014 tentang perlindungan anak yaitu agar anak tersebut mendapat perlindungan dan haknya sebagai anak juga dilindungi hak untuk hidupnya, tumbuh kembang dan berpartisipasi secara optimal sinkron serta harkat dan martabat kemanusiaan, beserta perlindungan hukum diberikan agar memperoleh perlindungan dari kekerasan dan diskriminasi yang akan menimpa anak. Sanksi pidana untuk pelaku kekerasan seksual kepada anak penyandang disabilitas termuat pada Pasal 285 dan 286 KUHP. Sanksi bagi pidana pelaku kekerasan kepada anak penyandang disabilitas saat ini belum ada peraturan yang mengatur secara khusus tetapi dalam UU No. 35 Tahun 2014 Tentang Perlindungan Anak tedapat pada Pasal 290 ayat (I) diancam dengan sekurang- kurangnya tujuh tahun kurungan penjara.

\section{Saran}

Berikut adalah saran yang peneliti berikan untuk arah perkembangan selanjutnya yakni kepada Pemerintah agar dibuatnya peraturan khusus untuk kasus kekerasan seksual terhadap anak penyandang disabilitas. Pada masyarakat dihimbau agar lebih memperhatikan anak penyandang disabilitas agar tidak menjadi korban kejahatan kekerasan seksual. Pada pelaku tindak kekerasan seksual seharusnya mendapatkan sanksi pidana yang tepat dan membuat efek jera.

\section{DAFTAR PUSTAKA}


Cahyani, Y. N., Verdiantoro, A. G., \& Uma, F. (2020). Perlindungan Hukum Bagi Korban Tindak Kekerasan Seksual Kaum Tunarungu dalam Perspektif Hukum Pidana. Mimbar Keadilan, Vol 13(2).

Gunarsa, S. D. (1992). Psikologi Rernaja. Gunung Mulia. Jakarta.

Gultom Madin. (2012). Perlindungan Hukum Terhadap Anak dan Perempuan. Refika Aditama. Bandung.

Hamza, A. (1993). Sistem Pidana dan Pemidanaan Indonesia. Pradnya Paramita. Jakarta.

Huraerah, A. (2006). Kekerasan Pada Anak. Nuansa Cendekia. Bandung.

Mukmin, A. (2020). Perlindungan Hukum Bagi Anak Penyandang Disabilitas Sebagai Korban Pencabulan Oleh Orang Tua. Dinamika, Jurnal Ilmiah Ilmu Hukum, Volume 26(3), 381-394.

Mohammad Hafidz, S.H., M.Hum. \& Firda Laily Mufid, SH., M. (2018). Perlindungan Hukum Terhadap Anak Korban Kekerasan Seksual (Studi Di Desa Sabrang Kecamatan Ambulu Kabupaten Jember). Jurnal Rechtens, Vol 7(1).

Soedarsono, 1997, Kenakalan Remaja, Rineka Cipta, Jakarta

Soedarsono. (1997). Kenakalan Remaja. Rineka Cipta. Jakarta.

Srilampau, S. (2009). Fenomena dan Perlindungan Hukum di Indonesia. PT. Sinar Grafika. Jakarta. 